School of Humanities and Social Sciences

English

n.kampmark@latrobe.edu.au

Holmesglen Institute of TAFE

English Language Centre

natasa.kampmark@holmesglen.edu.au

\title{
EAL IN VOCATIONAL EDUCATION: NEEDS ANALYSIS AND COURSE SYLLABUS DESIGN ${ }^{1}$
}

\begin{abstract}
After examining the role of a needs analysis approach in ESL/EAL ${ }^{2}$ and most common tools of varied efficiency and reliability used to conduct it, the paper explicates a development of a needs analysis tool for the purpose of designing a syllabus for an English language course for a group of international students and bringing their language competency to the level required for enrolment into a VET/TAFE course in Australia. Furthermore, the paper gives an overview of a five-lesson programme designed to address the perceived needs of overseas students and in its final section offers possible ways of evaluating the programme.
\end{abstract}

Key words: EAL, needs analysis, needs assessment tools, syllabus design, learning process, course evaluation.

\section{EDJ U STRUKOVNOM OBRAZOVANJU: ANALIZA POTREBA I IZRADA NASTAVNOG PLANA}

APSTRAKT: U radu se najpre razmatra uloga analize potreba u nastavi engleskog kao stranog, odnosno dodatnog jezika (ESJ/EDJ), nakon čega se daje pregled instrumenata kojima se analiza izvodi, te ukazuje na njihove prednosti i nedostatke. Središnji deo rada detaljno prikazuje konstruisanje instrumenta za analizu potreba s ciljem izrade plana rada

\footnotetext{
1 The paper is based on assignments completed as part of the Graduate Certificate in Teaching English as an Additional Language at Holmesglen Institute in Melbourne, Australia. I thank the course coordinator Marina Grishina and practicum supervisor Carly Gilligan and her class of students. The term 'syllabus' denotes 'specifications of topics, forms, assignments, and schedules for completion of a course' (Brown and Lee 2015: 638). The syllabus designed for the purpose of this research was delivered over the course of five weeks and is referred to in the paper as 'a five-lesson program'.

${ }^{2}$ Because the term ESL (English as a Second Language) presumes that English is a student's second language, which in most instances is not the case with ELICOS students in Australia, the term EAL (English as an Additional Language) is used.
} 
za kurs engleskog jezika namenjenog međunarodnim studentima čija jezička kompetencija mora dostići nivo potreban za upis na institucije strukovnog obrazovanja u Australiji (VET/TAFE). U radu se, zatim, izlaže petodelni nastavni plan, izrađen u skladu sa ustanovljenim potrebama, a na samom kraju rada daju se sugestije za ocenu uspešnosti sprovedenog plana.

Ključne reči: EDJ, analiza potreba, instrumenti za analizu potreba, izrada plana rada, proces sticanja znanja, evaluacija kursa.

\section{INTRODUCTION}

To enrol into vocational education and training programmes in Australia, international students need to meet required language standards, which range between IELTS bands 5.5 and 7, depending on the level of the main course they wish to take up (Certificate III, IV or Diploma, for example). To help them improve their English skills, but also to prepare them for further studies, various language centres, schools and institutes provide English language courses. The aim of this paper is to examine how the English Language Intensive Courses for Overseas Students (ELICOS) programme offered by Holmesglen Institute of $\mathrm{TAFE}^{3}$ in Melbourne could be tailored to a particular class of students and designed so as to increase the level of students' language competency while furthering their academic skills such as conducting research, writing reports or delivering oral presentations. As a result, a needs analysis tool, complementary to the Institute's existing tool, was designed and implemented and the data subsequently used to develop a five-lesson programme to address the students' needs. After the delivery of the programme, deliberations follow on how to measure the efficiency of the lessons and what areas of improvement could be.

\section{NEEDS ANALYSIS: DEFINITION, METHODS, ADVANTAGES AND DISADVANTAGES}

Emerging in the 1920s and gaining currency in the 1960s with the ESP movement (Li 2014; Simion 2015), the term 'needs analysis' in the context of language teaching refers to the process of collecting information about students. What may seem as a rather straightforward definition assumes complexity with considerations of what the term 'needs' actually denotes, what kind of information should be collected, what methods of data collection should be used, when needs analyses should be conducted, and why a needs analysis should be conducted in the

\footnotetext{
${ }^{3}$ TAFE stands for Technical and Further Education.
} 
first place. What are the benefits of a needs analysis and what might be its downsides?

Arguably the most encompassing definition has been given by the linguist Brindley (1984: 28), who defines needs as 'wants, desires, demands, expectations, motivations, lacks, constraints, and requirements', referring to what the students themselves hope to learn in the course. Very often 'needs' are perceived in terms of 'a linguistic deficiency' (Richards 2001: 54), that is, a gap between students' present linguistic competencies and anticipated future ones.

Needs are most commonly classified as objective and subjective (Brown and Lee 2015: 183-184) and in order to establish those needs, various types of information are gathered about students. Objective needs are typically inferred from 'factual information' (Brindley 1989: 70) such as biographical data, educational background, interests, previous language courses, current or future profession (that is, current and future context for English), current proficiency levels, and language skills which learners need to acquire. In contrast, the analysis of subjective needs relies on information about 'affective and cognitive factors' (Brindley 1989: 70) such as learners' personality, self-esteem, confidence, preferred learning strategies and attitudes toward the target language and culture.

To collect such a variety of information, a range of needs assessment tools have been developed, including questionnaires, observations and interviews (Dudley-Evans and St John 1998: 132; Long 2005: 30-32). Survey questionnaires are probably most practical, economic and least time consuming, especially with a large number of students. However, lack of depth and detail of information are some of the more significant disadvantages of this tool. Interviews (one on one or in small groups), on the other hand, provide more detailed information about what learners know and what their interests are, but they tend to be time-consuming. In practice, a combination of methods is used to determine student needs and special attention is paid to the appropriateness of the chosen tools for particular learners (Long 2005: 30-40).

Whether described metaphorically as a diagnosis before the doctor's prescription (Long 2005: 20) or more pointedly as 'an important precursor to designing the goals of a course' (Brown and Lee 2015: 183), benefits of a needs analysis are manifold. Usually preceding the designing of a course, a needs analysis is intended to reduce any gaps between learners, teachers and teaching materials. As such, it plays a crucial role in understanding students' needs and helping the implementation of educational policies. Furthermore, it helps teachers select and tailor the course content and set course goals. Moreover, depending on learners' expectations, it can be used by teachers to modify the syllabus and 
methodology as well as to adjust teaching approaches to students' learning styles. In addition, a well-designed needs analysis can discover which particular language skills learners need in order to perform a particular task and how large the gap is between their present proficiency and the one required for the role. A needs analysis can also reveal the most problematic areas for learners so that they can be addressed accordingly. Having in mind these benefits, it is clear that a needs analysis can help position teachers, learners, teaching materials, approaches and methods so as to enhance the outcomes of the learning process. In other words, without a needs analysis, there would be a high risk of discrepancy between the goals and purposes of a course as designed by the teacher and learners' actual needs, which could lead to learners' confusion about why they are learning something and why they are doing so in a given way.

However, there are also some problems concerning the process and outcomes of a needs analysis. If the most appropriate tool or a combination of tools is not used to determine students' needs, the results may be unreliable. For example, if students do not understand questions in a questionnaire, their answers most likely will not reflect their needs. Furthermore, if students are only familiar with teacher-centred approaches, they might think that the course design is entirely the teacher's responsibility. Envisaging students as dynamic individuals, Banforth (1996) also argues that learners can change their minds or their needs during a course. That is why she suggests that a needs analysis should be conducted not only prior to the course but during the delivery of the course, too.

On balance, advantages of a needs analysis seem to carry more weight than their disadvantages and, for all their shortcomings, attempts to find out about learners' needs (as defined earlier) can only contribute towards a more successful learning experience for both learners and teachers.

\section{RESEARCH METHODOLOGY}

The needs analysis tool already developed at Holmesglen Institute takes the form of an individual learning plan and consists of three parts: student profile, mid-course review and end-of-course review (see Appendix 1). In its five sections (personal details, education, goals, skills areas, and a writing sample of 100-150 words), the student profile is designed to collect both factual and cognitive data. Factual information for an objective needs analysis includes biographical data, educational background, a target context for language use, language skills to be addressed, and possible obstacles to their learning. Cognitive data is collected through questions about students' expectations from the course, specific skills they 
feel they need to improve, and learners' habits and attitudes to learning English outside class. Finally, students are asked to produce a piece of writing about themselves, their background and their goals.

For my needs analysis, I decided to use a questionnaire and a hundredword-long piece of writing. I thought that a questionnaire would be appropriate for students whose command of English ranges from intermediate to upper intermediate, and who must have encountered that type of tool in the course of their education. ${ }^{4}$ Like the Holmesglen ILP, my questionnaire was designed to collect both objective and subjective information about students. In my opinion, the most significant addition in my questionnaire (see Appendix 2) are questions 7, 8 and 9, whose purpose is to determine students' preferred learning styles and strategies. That aspect is missing from the pre-existing tool. Furthermore, I thought that the contextualisation of questions about language skills in question 4, which placed students in actual reading, listening, speaking and writing experiences, would yield more genuine data than naming the skills out of context. Similarly, instead of an open question of the pre-existing tool about areas students hope to improve, ${ }^{5}$ I decided to list six skills and areas and have students grade them according to personal importance. ${ }^{6}$ Finally, the writing sample on the topic of hobbies and free time was designed to reveal both writing skills (coherence, cohesion, range of vocabulary, grammar etc.) and their interests, with the aim of incorporating them into lessons.

Based on the two needs analyses, a profile of the class emerges, consisting of $22^{7}$ international young adult students predominantly from Asian and South American countries. The highest level of education in a majority of them is high school, and the goal of the ELICOS course they are enrolled into is to improve their English in order to pursue their interests in terms of their future studies, which consists mainly of Certificates III or IV in a range of courses in the VET/TAFE sector (e.g. Certificate IV in Hospitality).

\footnotetext{
${ }^{4}$ I learned about their educational background from Holmesglen designed ILPs which they had completed.

${ }^{5}$ This appeared to be misunderstood by some students who listed things such as 'glazing'.

${ }^{6}$ Knowing that every lesson actually addresses all skills, my aim here was to determine not only one skill which students think is most important to improve but to get a full list of preferences.

${ }^{7}$ Holmesglen ILPs were completed by 22 students. However, there were 17 students present on the day when I conducted the needs analysis.
} 


\section{PRESENTATION OF THE RESULTS}

This section details the needs analysis outcomes by a numerical analysis of data collected through the questionnaire and by categorising types of errors which occurred in samples of students' writing. This is followed by a description of a five-lesson programme, designed to address the perceived needs of students while observing their preferred learning styles. Individual lessons are presented in terms of the type of texts used in the lesson, aims of the lesson, and individual stages of the lesson with examples of activities.

\subsection{Needs Analysis Outcomes}

The questionnaire revealed that students would greatly benefit from the improvement of their skills of listening and comprehension because eleven out of seventeen students who participated in the needs analysis found that understanding news and TV programmes was the most difficult activity for them. In addition, fourteen of them indicated that they can understand 'some' when spoken to. Listening also ranks high in the direct question about the skill they want to learn most with half the students placing it as either 1 or 2 on the list.

In terms of learning styles, group work (12 students) is overwhelmingly preferred over individual ( 2 students) or pair work (3 students), and the most useful way of learning for them seems to be by way of listening to the teacher's explanations (auditory type), followed by reading and watching videos. These two findings are reinforced by answers to question 9, where the most enjoyable learning experience for most students was revealed to be when they worked in groups and listened to the teacher.

Interestingly, in decontextualized questions of the pre-existing tool, the skills that students indicated as the ones they need and want to improve were the skills of speaking and writing, closely followed by listening and reading.

The writing samples show that students need to work on the length of their written pieces, discourse markers and signposting language, prepositions, articles, punctuation and specific grammatical structures (e.g. like + -ing vs. 'd like to + inf.; enjoy + -ing).

\subsection{Learning outcomes and the five-lesson programme}

The students are enrolled in English for Further Studies 1 course and are studying for the English for ELICOS qualification. The course has five components and five corresponding topics, activities and assessments as follows: 
- Independent learning strategies - submit ILP and create a study plan;

- Reading, note taking, paraphrase - Skimming, scanning, and comprehension;

- Listening comprehension and note taking - pre-listening strategies and comprehension;

- Essay Writing - features and structure of paragraphs in academic writing;

- Oral presentations - presentation skills, structure, planning, outlining points, visual aids.

Following insights from the needs analysis, I have decided to structure my five-lesson programme around the skill of listening with extension activities of writing and speaking. The programme is designed to address some of the listening strategies and skills such as listening for specific information (with the prelistening tasks such as predicting, identifying key words and changing pictures into words), understanding what speakers are saying with the focus on understanding vocabulary and learning useful words (e.g. decoding prefixes and suffixes), listening for explanations of problems and solutions, listening for arguments and listening for stories. The activities are structured mainly as group work as the preferred learning strategy, with noticing and elicitation followed by the teacher's explanation (confirmation of elicited information). The focus is on academic content as this is an English for Further Study course and listening tasks and activities are modelled on the IELTS test because most learners from this class need to achieve an adequate IELTS score to be admitted to their preferred course of further studies.

The five-lesson programme proposed here is intended to develop students' listening skills using a variety of approaches. The cognitive approach is reflected in the importance placed on practice in order to achieve automaticity (Lightbown and Spada 2013: 117-118), with activities moving from structured to more open-ended ones. A combination of the cognitive and socio-cultural approaches is adopted mainly for pre-listening activities which start with questions aimed at mobilizing students' prior knowledge and adding personal significance to the construction of language (Vygotsky in Mitchell et al. 2013: 220-246). The communicative approach is reflected in the frequent use of small-group and pair activities such as gap activities, jigsaw activities, and role-play (Richards 2006: 14-21; Brandl 2007: 284-297). In addition, receptive activities are tied to productive activities, that is, listening is tied to speaking and writing. Finally, the programme is based around spoken texts which are used as models of texts that the learners are required to 
master. In other words, elements of the text-based approach run through the fivelesson programme, with lesson 4 closely following the text-based approach as outlines by Feez (1998: 28-31).

The proposed programme meets the students' needs insofar as a prior needs analysis established that students would benefit from an improvement of their listening and comprehensions skills. In addition, listening ranked high on the list of skills students would prefer to develop further. In terms of the demands of the curriculum, the five-lesson programme meets the English requirements for ELICOS qualification because it directly addresses one of the five components of the course: Listening comprehension and note taking - pre-listening strategies and comprehension.

The five lessons in the mini programme are, therefore, linked by the same skill which is in focus. Furthermore, there is a variety of text types which are graded from a chronological narrative to a news item, following the problemreasons-solution structure, to a discussion with four participants and a moderator. The goals of the programme are for students to:

- master some pre-listening strategies (e.g. predict type of information),

- listen for gist,

- listen for detail / specific information,

- take note of key words,

- became aware of text types and their aspects,

- produce a summary with prompts, and

- participate in a discussion.

\subsubsection{Lesson 1}

Lesson 1 is based on a narrative text, an anecdote with an open-ending to encourage students to be creative in the production phase. The text comes from the field of sport because in the needs analysis questionnaire, a number of students have indicated watching or doing sports as a pastime activity they enjoy. The choice of the text for the first lesson of the programme is, therefore, guided by the intention to incorporate students' real life interests. The material used for the lesson is from Mind Twisters, Puzzles and Games by Southern and Wallwork.

The aims of this lesson are: to develop the pre-listening strategy of changing pictures into words; to listen for gist; to listen for specific information; to practise listening to a story (as a type of text which appears at the IELTS exam); to practise taking notes while listening; and to retell the story in their own words (in a 
group as joint construction, and individually as homework). Language which is in focus in this lesson is the first conditional because there are several examples of this structure in the story. Vocabulary is not in focus but words such as 'hooligans' or collocation 'cancel the debt' are explained.

The first stage of the lesson is dedicated to setting the context, identifying the topic and eliciting vocabulary. In this stage students are also taught the prelistening strategy of changing pictures into words because it is an important skill to master in preparation for exams such as the IELTS. Students need to decide what to listen for when the question contains pictures. In this pre-listening activity, students work in groups and are directed to locate different details in the pictures and express them in words. They are also instructed to have a go at sequencing the pictures and predicting the flow of the narrative.

The next stage is dedicated to listening for comprehension. First, they listen to check the order of pictures. When the order is established, the pictures are discussed in terms of key characters and the order of events (setting the stage, complication, and possible resolution). Next, students listen to the story two more times in order to write down key words for each picture. Students work in groups and use the key words and the pictures to jointly tell the story in their own words. Students are given butchers paper to write their stories down. Independent construction is set as homework and the students are instructed to supply the ending / resolution to the story.

Key language that is studied in this lesson is the first conditional. The examples of the construction are taken from the story and the form (the present simple in the if-clause, the future simple in the main clause) and meaning are elicited (real time, future result).

\subsubsection{Lesson 2}

Lesson 2 is based on the news item 'Coral Spawning' found on BTN. The text is chosen as an example of the problem-reasons-solution structure of the text as one of the possible types which occurs at the IELTS exam. The topic of Australian natural landmarks and their protection is chosen so as to tie in with the topic and type of texts which students are exploring for the writing task. It means that the texts analysed in other classes are referred to as examples of related texts.

The aims of this lesson are: to develop the pre-listening strategy of predicting the type of information based on question words (i.e. determining whether to listen for time, date, number, location etc.); to practise listening for the 
presentation of problems, explanation of reasons, and possible solutions; to practise listening for specific information.

The image and introduction into the video are used to set the context and identify the topic. Australian natural landmarks are discussed in general and PowerPoint slides are used to further contextualise the Great Barrier Reef and its protection. Vocabulary from the introduction (coral, spawning, reef, reproduce) is explained. As students listen for the first time, they are asked to think about one question: 'Why are scientist worried?' (coral cover has dropped/coral is dying). In the next stage, students practise to predict the type of information. This is done as individual and pair activity. Students fill in the charts to predict the type of information and then listen for details (e.g. Where is the Great Barrier Reef?; predict the type of information: location; answer: Queensland). Identifying the key stages of the text is done as a competitive group activity. Each group is given a set of cards containing the problem, reasons and solution, and some extra cards. Their task is to listen to the recording and sort out the cards under three headings on the whiteboard which correspond to three stages of the text.

\subsubsection{Lesson 3}

Lesson 3 is the continuation of Lesson 2. The aims of this lesson are: to practise listening and gap-filling; to develop vocabulary (adjectives); to practise the first and zero conditionals; to construct a summary of the text following the problem-reasons-solution stages.

This lesson starts with a vocabulary quiz in order to mobilise the students' knowledge from the previous lesson. The vocabulary focus is sustained in the gap filling task. Students are given the summary of the 'Coral Spawning' and certain adjectives are missing from the text. They have the same form as in the original text. Students are first asked to identify the type of words which are missing and then to listen and fill in the gaps. They should do the task first individually and then check in pairs and groups. After revealing the answers, the words are analysed as a class activity. The emphasis is on suffixes which are used to make adjectives from verbs and nouns.

The next stage focuses on the structure of the text as students are asked to identify the introduction of the problem, the explanation of the reasons and the solution. In addition, students are asked to identify the key language used for each of these stages as well as to identify the signposting language. The summary is set 
as a model for the students to write their own summary of 'Coral Spawning' for homework. $^{8}$

The next stage focuses on language/grammar and builds up on the grammar of lesson 1. Examples of the first and zero conditionals from 'Coral Spawning' are used to revise the first conditional and to introduce the zero conditional. Examples are compared and form and meaning are elicited. Students practise the zero conditional in a fun activity which involves finding a partner with the ending / beginning of your sentence (sentences are superstitions from around the world). Depending on the time, a chain game can also be used to practise the target structure. A nice ending to the lesson can be a song containing both target structures, with the task of putting the lyrics in order. All students have indicated in the needs analysis questionnaire that they like listening to songs in English.

\subsubsection{Lesson 4}

This lesson closely follows the text-based approach. The text used in this lesson is a discussion with four participants (students) and a moderator (tutor). The text is taken from Focusing on IELTS: Listening and Speaking by O'Sullivan and Thurlow (exercise 8, recoding 10). The text is chosen as a model of a text which can appear at the IELTS exam. In addition, the students can relate to the tenor of the text; the situation, topic and speakers are not unlike those in their own classroom.

The aims of this lesson are: to learn to listen to arguments / conversations / debates; to demonstrate understanding of a spoken text (conversation) by answering gist and detailed questions; to practise matching the meaning (focusing on more than one question); to identify examples of language for expressing a position / opinion / viewpoint and expressing their agreement / disagreement; to use language for expressing a position / opinion / viewpoint and expressing their agreement / disagreement (role play debate).

The first stage serves the purpose of building the context for the type of text and topic. It is done as a teacher-led discussion about who politicians are and what their job is. Pre-teaching vocabulary is done in three phases. In phase one, students are given worksheets and asked to match words and their definitions (individually and in pairs). Phase two consists of a PowerPoint presentation of

\footnotetext{
${ }^{8}$ Individual writing tasks are set for homework (in Lesson 1 and Lesson 3) because my focus is on the listening and comprehension skills.
} 
words, pronunciation, illustrations and use in context. In phase three, students are asked to complete sentences in their worksheets with the words.

The second stage is modelling and deconstructing the text. In this phase students listen to the text while gist questions are placed on the whiteboard. After that, students are given worksheets with detailed questions about the text. They are asked to read the questions and ask for clarification if needed. Instructions are given that they will listen to the recoding 3 times and will have 5 minutes after each listening to attempt answering the questions. This is followed by peerchecking, class discussion of answers and the study of key language after that. In this phase, students are given transcripts of the recording and work in pairs to identify the language to express opinion, agreement and disagreement. Answers are, then, compared in groups and expressions written on the whiteboard. In the next phase students focus on the structure to notice how expression of opinion is followed by explanations / arguments. This is done as a group activity. The students are then asked to make a list of opinions expressed in the text and find supporting arguments / explanations. They write on butchers paper and use their notes in the next stage, which is the joint construction. In this stage, the students are asked to discuss whose viewpoint they agree or disagree with. In preparation for the independent construction, the students are asked to write down their own view about what makes good politicians and to offer supporting arguments. Joint construction is then done as the students are divided into groups and instructed to use the language and structure of the model text to develop a discussion based on their own views and arguments (i.e. to express the view and in turn agree or disagree with others in the group). An example of a related text is given in the next lesson.

\subsubsection{Lesson 5}

Lesson 5 has two parts. The aim of the first part is to conduct formative assessment of students' listening skills modelled on the summative assessment at the end of their course, while the aim of the second part is for the students to compare this text with the one in the previous unit, thus completing the last stage of the text-based approach.

The same type of text (discussion / debate) is used as in Lesson 4 and assessment tasks follow the model of detailed questions which students have the chance to practise in Lesson 4. The four types of assessment tasks are as follows: true / false / not given; multiple choice; gap-filling, and vocabulary. The text is taken from Focusing on IELTS: Listening and Speaking by O'Sullivan and 
Thurlow (exercise 30, recoding 32). The text is chosen because of its type and topic. Being a discussion with expression of opinions followed by justification, it serves as a text which students can compare with the text from the previous unit. This is an example of a more informal setting (home vs. classroom) and informal discussion between students on a topic relevant for them - continuous assessment vs. end-of-course exam. In addition, the text offers examples of question tags and this grammar point can be practised as a fun jig-saw activity.

Given that the first part of the lesson is a form of continuous assessment, this is an excellent opportunity to end the mini programme with a debate on the advantages and disadvantages of continuous assessment.

\section{SUGGESTIONS FOR THE EVALUATION OF THE PROGRAM}

Any evaluation of a programme designed to meet students' needs as identified by a needs analysis should establish if the goals of the programme as well as the objectives of individual lessons are met. With that aim in mind, for each individual lesson the teacher could make a checklist containing objectives of that particular lesson. For Lesson 1 of the programme detailed here, for example, such a checklist could look like this:

1. __ develop the pre-listening strategy of changing pictures into words,

2. __ listen for gist,

3. __ listen for specific information,

4. _ practise listening to a story,

5. _ practise taking notes while listening,

6. _ retell the story in their own words,

7. _ use the first conditional.

The more ticks on the checklist, the more successful the lesson.

Furthermore, evaluation should ascertain if students benefited from the programme and if their particular language skills improved as a consequence. This also refers to the students' individual and group oral and written performance in the course of the five lessons, where students' production of the text type, grammatical structures and vocabulary can be interpreted as an indicator of to what extent the programme was beneficial for students (in terms of which skills they learned and how they relate to the overall curriculum). This part of the evaluation process could be accomplished by monitoring students' oral and written production in individual classes and then at the end of the programme by a purposefully designed 
assessment tool to test the skills which the programme is designed to improve. The success of Lesson 1, for example, is evaluated by students' satisfactory (S) or nonsatisfactory (NS) oral and written production in class and satisfactory completion of tasks set as homework. A checklist of tasks can be used by the teacher and filled in by "S" or "NS". For example:

1. _ discussion of the pictures,

2. _ predictions made based on the pictures,

3. _ joint construction,

$3 \mathrm{a} \_$_ relevant vocabulary,

$3 \mathrm{~b} \_$_ grammar,

$3 \mathrm{c}$ _ text organisation.

The more satisfactory (S) outcomes, the more successful the lesson.

In addition, an effective way to evaluate the programme is formative assessment, conducted by means of a test designed to assess the extent to which students' acquired the skills that the programme focused on. (For the assessment tool specifically designed to assess students' listening and comprehension skills at the end of the mini programme, which has already been described under subheading "Lesson 5", see Appendix 3.)

The evaluation should also include students' interest and engagement, which reflect their judgement on the relevance of both the material and skills practised. This segment of evaluation could make note of the strategies, activities and materials which proved to be most useful in achieving the objectives in so far as they were engaging for students, stimulated their production and generated the most beneficial response from them. It could be conducted by using a questionnaire for students to complete at the end of the programme. Such a survey could include questions such as:

1. Which activities / tasks did you enjoy doing? Why?

2. Which texts / videos / recordings can you remember reading / listening / watching in class?

3. Which texts / videos did you like most? Why?

\section{CONCLUSION}

The evaluation of the programme designed to address the gap between students' competencies before the start of the programme and the ones required to 
enter a VET/TAFE course can provide a basis for improvement of a future programme. Despite the fact that the same programme is unlikely to be delivered to a different class of students - as their needs are presumably different - the teacher can still reflect on general areas of development. For example, the programme detailed in this paper could suggest that a future programme should be less ambitious in terms of activities and allow more time and more scaffolding or variations / extension for group discussions or writing; that it should use the whiteboard more and PowerPoint less, especially when presenting grammar; have more practice of pronunciation and sentence intonation; and resort more to eliciting rather than explanation. In conclusion, a successful course syllabus design relies on both an efficient needs analysis and a careful evaluation of previously designed courses.

\section{SOURCES}

"Coral Spawning." Australian Broadcasting Corporation. Accessed 17/03/2018. URL: 〈http://www.abc.net.au/btn/story/s4765561.htm>.

O'Sullivan, K. and Thurlow, S. (2002). Focusing on IELTS: Listening and Speaking. Sydney: National Centre for English Language Teaching and Research.

Southern, A. and Wallwork, A. (2004). Mind Twisters, Puzzles and Games. London: Mary Glasgow Magazines.

\section{REFERENCES}

Banforth, J. (1996). "Needs analysis in the adult ESL classroom". Changing Education: A Journal 3 (4): 13-14.

Brandl, K. (2007). Communicative Language Teaching in Action: Putting Principles to Work. Upper Saddle River, NJ: Phil Miller.

Brindley, G. (1984). Needs Analysis and Objective Setting in the Adult Migrant Education Service. Sydney: NSW Adult Migrant Education Service.

Brindley, G. (1989). "The role of needs analysis in adult ESL programme design", in The Second Language Curriculum, ed. R. Johnson (Cambridge: Cambridge University Press): 35-70.

Brown, H. D. and Lee, H. (2015). Teaching by Principles: An Interactive Approach to Language Pedagogy (4th ed). New York: Pearson. 
Dudley-Evans, T., and St John, M.J. (1998). Developments of English for Specific

Purposes: A Multi-disciplinary Approach. Cambridge: Cambridge University Press.

Feez, S. (1998). Text-based Syllabus Design. Sydney: NCELTR Macquarie University.

Li, J. (2014). "Literature Review of the Classifications of 'Needs' in Needs Analysis Theory". International Journal of Education and Literacy Studies 3: $12-16$.

Lightbown. P. M. and Spada, N. (2013). How Languages are Learned. (4 ${ }^{\text {th }}$ ed.). Oxford: Oxford University Press.

Long, M. H. (2005). Second Language Needs Analysis. Cambridge: Cambridge University Press.

Mitchell, R., Myles, F., and Marsden, E. (2013). Second Language Learning Theories ( $3^{\text {rd }}$ ed.). London and New York: Routledge.

Richards, J. C. (2001). Curriculum Development in Language Teaching. Cambridge, UK: Cambridge University Press.

Richards, J. C. (2006). Communicative Language Teaching Today. New York: Cambridge University Press.

Simion, M. O. (2015). "Needs Analysis in English for Specific Purposes". Annals of the ,Constantin Brâncuşi” University of Târgu Jiu 1 (2): 54-55.

Nataša V. Kampmark

La Tobe Univeristy

School of Humanities and Social Sciences

English

Holmesglen Institute of TAFE

English Language Centre

\section{EAL U STRUKOVNOM OBRAZOVANJU: ANALIZA POTREBA I IZRADA NASTAVNOG PLANA}

\section{Sažetak}

U radu se najpre daje kratak pregled definicija termina "analiza potreba", objašnjava se značajna uloga koju ona ima u nastavi engleskog kao dodatnog jezika (EAL), da bi se, zatim, razmotrili različiti instrumenti, poput upitnika, opservacije i intervjua, koji se koriste za prikupljanje subjektivnih i objektivnih podataka o studentima. Nakon toga, opisuje se istraživanje koje je obuhvatalo izradu instrumenta za analizu potreba u cilju prikupljanja podataka o grupi polaznika intenzivnog kursa engleskog jezika za međunarodne studente (ELICOS) na Institutu Holmesglen u Melburnu. Prikupljeni podaci su iskorišćeni za izradu petodelnog nastavnog plana s namerom da se premosti jaz između ustanovljene jezičke kompetencije studenata i kompetencije potrebne za upis na institucije strukovnog 
obrazovanja (VET/TAFE) u Australiji. Nastavni plan imao je za cilj unapređenje veština slušanja i razumevanja uz pomoć niza nastavnih metoda i pristupa (npr. tekstualni, komunikacijski, kognitivni). U radu se, zatim, opisuju ciljevi, aktivnosti, strategije i materijali korišćeni u nastavi. Na kraju rada daju se sugestije za evaluaciju nastavnog plana i predlažu se instrumenti poput kontrolnih lista, upitnika i testova kojima bi se moglo ustanoviti da li su ostvareni ciljevi kako pojedinačnih lekcija tako i celokupnog programa, kao i da li studenti bolje vladaju jezičkim veštinama nego pre izvođenja petodelnog nastavnog plana.

Ključne reči: EAL, analiza potreba, instrumenti za analizu potreba, izrada plana rada, proces sticanja znanja, evaluacija kursa.

Received: 2 March 2019

Accepted: 3 July 2019 
Appendix 1

HOLMESGLEN LANGUAGE CENTRE LEARNING PLAN

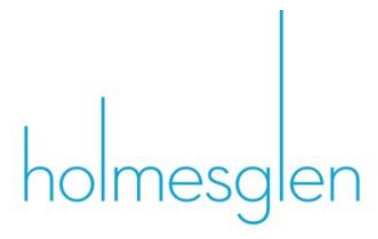

Full Name:

English name:

Category:

Class Code:

ELICOS

E4FS201ECA/181

Student ID:

Weeks of Study:

Email:

Entry IELTS:

S

$\mathrm{L} \_\mathrm{R}$

W Overall:

Entry ISLPR:

$\mathrm{S}_{-} \mathrm{L}_{-} \mathrm{R} \_\mathrm{W}$

Class Coordinator:

Date: 


\section{STUDENT PROFILE}

\section{Personal Details}

Name

Country of origin

Arrival date in Australia

\section{Education}

What qualifications do you have from your country?

Have you studied at Holmesglen before? If so, what course/level?

\section{Goals}

What are your future study plans?

Intended Course:

Intended start date:

Language Entry Requirement for your intended course:

IELTS required:

/ ISLPR required:

What English skills do you think you will need to succeed with your future study goals?

What do you think your strengths are in English?

e.g.reading/writing/speaking/listening/pronunciation/grammar/vocabulary

What areas do you hope to improve by studying this course?

Outside of class, what can you do to ensure you achieve your goals?

\section{Which areas of English do you find the easiest or most difficult?}

(Tick $\square$ the appropriate box for each area)

\begin{tabular}{|l|l|l|l|l|l|}
\cline { 2 - 5 } & $\begin{array}{l}\text { Very } \\
\text { easy }\end{array}$ & Easy & $\begin{array}{l}\text { Neither } \\
\text { easy nor } \\
\text { difficult }\end{array}$ & Difficult & $\begin{array}{l}\text { Very } \\
\text { difficult }\end{array}$ \\
\hline Reading & $\square$ & $\square$ & $\square$ & $\square$ & $\square$ \\
\hline
\end{tabular}




\begin{tabular}{|l|l|l|l|l|l|}
\hline Writing & $\square$ & $\square$ & $\square$ & $\square$ & $\square$ \\
\hline Speaking & $\square$ & $\square$ & $\square$ & $\square$ & $\square$ \\
\hline Listening & $\square$ & $\square$ & $\square$ & $\square$ & $\square$ \\
\hline Grammar & $\square$ & $\square$ & $\square$ & $\square$ & $\square$ \\
\hline Vocabulary & $\square$ & $\square$ & $\square$ & $\square$ & $\square$ \\
\hline $\begin{array}{l}\text { Understanding your } \\
\text { friends/classmates at } \\
\text { school }\end{array}$ & $\square$ & $\square$ & $\square$ & $\square$ & $\square$ \\
\hline $\begin{array}{l}\text { Understanding teachers at } \\
\text { school }\end{array}$ & $\square$ & $\square$ & $\square$ & $\square$ & $\square$ \\
\hline $\begin{array}{l}\text { Understanding local } \\
\text { people (Aussies) outside } \\
\text { of school }\end{array}$ & $\square$ & $\square$ & $\square$ & $\square$ & $\square$ \\
\hline
\end{tabular}

How much time can you set aside for homework every day?

Will you be working during your study? How many hours a week?

Do you have any problems which might make it difficult to study? (eg family, finances, health, housing)

5. Write a short letter to your teacher, introducing yourself, your educational background, and your goals. Write about 150 words. 


\section{Mid-Course Review}

Progress - Please tick the things you do

I come to class regularly and participate well $\square \quad$ I do homework every day $\square$ I use teacher recommended resources in the ILC in my own time $\square$

I use English outside the classroom $\square$ I participate in self - study How do you think you have improved over the last term? Give examples

What can you do next term to improve your English?

Date

\section{End of Course Review}

I have reviewed my assessment tasks and received feedback from my teachers. Yes No

I have achieved my goals for this course. Yes No

Comment

Signature of student

Signature of teacher

Date 
Appendix 2

NAME:

DATE:

1. Where do you come from?

2. How long have you been in Australia?

3. What will you do after the English course? Do you want to continue studies (which courses are you interested in?) or find a job (which jobs are you interested in)?

4. How difficult are the following situations for you in English? Number the situations from 1 to 5 . Number 1 is the most difficult and number 5 is the easiest for you.

talk about yourself and your country with a friend talk about your education, experience and interests in a formal situation (such as a job interview or entry interview for a course)

read a story in the newspaper or a magazine understand the news and programmes on TV

write an email to your teacher explaining your absence from class and asking what to prepare for the next class

5. How much can you understand when people speak English to you? Circle what is true for you.

everything

most

some

a little

very little

6. What would you like to learn most? Number the skills from 1 to 6 . Number 1 is the most important skill and number 6 is the least important skill to you now. ___ Reading Listening Speaking Vocabulary Pronunciation 
7. Which type of activities do you enjoy most in class? Circle a, b or c.

a. Individual work

b. Group work

c. Pair work

8. When learning English, what is most useful to you? Circle a, b, c or d.

a. Listening to the teacher's explanations

b. Watching videos

c. Reading and discussing a text

d. Making a poster

9. Think back to a useful and enjoyable learning experience in the past. What made it so good for you?

10. How often do you do these things? Tick $(\sqrt{ })$ the box.

\begin{tabular}{|l|l|l|l|l|l|}
\hline & Never & not often & sometimes & Often & every day \\
\hline $\begin{array}{l}\text { Study in the } \\
\text { library }\end{array}$ & & & & & \\
\hline $\begin{array}{l}\text { Read } \\
\text { newspapers / } \\
\text { magazines / } \\
\text { books / online } \\
\text { texts in } \\
\text { English }\end{array}$ & & & & & \\
\hline $\begin{array}{l}\text { Watch TV in } \\
\text { English }\end{array}$ & & & & & \\
\hline $\begin{array}{l}\text { Listen to } \\
\text { songs in } \\
\text { English }\end{array}$ & & & & & \\
\hline $\begin{array}{l}\text { Write English } \\
\text { outside class }\end{array}$ & & & & & \\
\hline $\begin{array}{l}\text { Speak English } \\
\text { outside class }\end{array}$ & & & & & \\
\hline
\end{tabular}

11. Write about what you like doing in your free time? Do you have a hobby? What are your interests outside of studies or work? Write about 100 words.

Thank you for completing this questionnaire. 
Appendix 3

Listening Task Name: Continuous Assessment Answer the questions while you listen.

You will hear the audio track three times.

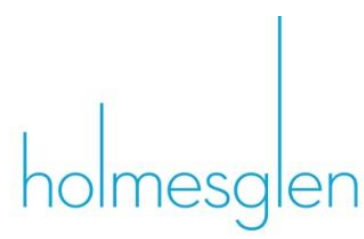

Mrs Blake, Tom, Julie and Diane are talking about 'continuous assessment'. Listen to their conversation and answer the following questions.

I Are the following statements true (T), false (F) or not given (NG)?

1) The discussion is taking place in a café. ...........

2) Mrs Blake is Tom's Mum. ...........

3) Diane likes Mrs Blake's cakes.

4) Tom wants his friends to stay a little longer.

\section{Circle the correct answer in the following:}

5) 'Continuous assessment' means that

a. students' assignments are marked during the year

b. students have one formal examination at the end of the year

c. students can choose when to finish their assignments

6) In Tom's opinion, continuous assessment is

a. good because it is less painful for students

b. bad because students are under pressure all the time

c. neither good nor bad, but it is important to participate in tutorials

7) Which of the following best describes Diane's opinion?

a. She likes assignments and always finishes them early.

b. She dislikes assignments but dislikes the formal examination more.

c. She cannot decide which method of assessment she likes more.

8) Julie is
a. in favour of sitting the final exam
b. against sitting the final exam
c. in favour of continuous assessment 


\section{Fill in the gaps in the following summary paragraph. Use ONE adjective per gap.}

A group of students are discussing their assignments. Some hate continuous assessment because they think it is the (9) pressure. Instead, they prefer one formal examination because it is less (10) than endless assignments. On the other hand, others get really (11) having to do an exam. They think that with continuous assessment they have got a (12) chance of getting a (13) mark.

\section{In the following, circle the synonym of each underlined word.}

14) The house is worth one million dollars.
a. has the growth of
b. has the value of
c. has the mark of
d. is the symbol of

15) When do we have to hand in our essays?
a. write in hand
b. draft on paper
c. give to teacher
d. choose a topic

16) Which method of assessment do you prefer?
a. like more
b. like less
c. dislike
d. reference 